\title{
Chapter 9 \\ Modeling Urban Futures: Data-Driven Scenarios of Climate Change and Vulnerability in Cities
}

\section{Ortiz, A. Mustafa, B. Rosenzweig, Rocio Carrero, and Timon McPhearson}

\begin{abstract}
Cities are complex systems where social, ecological, and technological processes are deeply coupled. This coupling complicates urban planning and land use development, as changing one facet of the urban fabric will likely impact the others. As cities grapple with climate change, there is a growing need to envision urban futures that not only address more frequent and intense severe weather events but also improve day-to-day livability. Here we examine climate risks as functions of the local land use with numerical models. These models leverage a wide array of data sources, from satellite imagery to tax assessments and land cover. We then present a machine-learning cellular automata approach to combine historical land use change with local coproduced urban future scenarios. The cellular automata model uses historical and ancillary data like existing road systems and natural features to develop a set of probabilistic land use change rules, which are then modified according to stakeholder priorities. The resulting land use scenarios are evaluated against historical flood hazards, showcasing how they perform against stakeholder expectations. Our work shows that coproduced scenarios, when grounded with historical and emerging data, can provide paths that increase resilience to weather hazards as well as enhancing ecosystem services provided to citizens.
\end{abstract}

The original version of this chapter was revised by adding Dr. Rocio Carrero to the author group. The correction to this chapter is available at: https://doi.org/10.1007/978-3-030-63131-4_13

L. Ortiz $(\varangle) \cdot$ A. Mustafa $\cdot$ R. Carrero $\cdot$ T. McPhearson

Urban Systems Lab, The New School, New York, NY, USA

e-mail: ortizl@newschool.edu

R. Carrero

e-mail: carrero.r@gmail.com

B. Rosenzweig

Environmental Science, Natural Sciences and Mathematics, Sarah Lawrence College, Bronxville, NY, USA

T. McPhearson

Cary Institute of Ecosystem Studies, Millbrook, NY, USA

Stockholm Resilience Center, Stockholm University, Stockholm, Sweden

(C) This is a U.S. government work and not under copyright protection in the U.S.;

foreign copyright protection may apply 2021, corrected publication 2021

Z. A. Hamstead et al. (eds.), Resilient Urban Futures, The Urban Book Series,

https://doi.org/10.1007/978-3-030-63131-4_9 
Keywords Urban development scenarios • Land use/cover change modeling • Hazard $\cdot$ Mapping $\cdot$ Climate vulnerability

\subsection{Data-Driven Models of Urban Land Use and Climate Hazards}

Often, urban development scenarios focus on global climate change impacts on existing infrastructure (Ortiz et al. 2019). Although some studies have explored the impacts of projected urban expansion, traditional approaches are often based on planning documents (Krayenhoff et al. 2018) or negative frameworks of the future (Coumou and Robinson 2013). As cities become more aware of the climate-related challenges ahead, spatially explicit models of heat risk, flooding, and other hazards are developed to address present and expected challenges. This chapter explores applications of data-driven approaches to estimate present and future risks related to weather hazards. The modeling efforts detailed in upcoming sections focus on land cover as a driver of heat and local flood hazards. By leveraging a wide array of data sources, from satellite imagery to tax assessments and land cover, models of present and future risk can be developed based on statistical and physical relationships between the land surface and climatological processes. Finally, land use/cover (LUC) models are introduced as a tool to develop future development scenarios. With LUC as a driver of weather hazard frequency and intensity, the combination of these models can provide stakeholders a tool to not just explore envisioned landscapes but also show their impacts on these risks across spatial and temporal domains.

The sections that follow introduce a modeling framework, detailed through a series of case studies focusing on two sites: San Juan, Puerto Rico and New York, New York. As coastal cities, San Juan and New York are exposed to similar hazards, such as flooding and sea-level rise. Each case study city, however, features vastly different infrastructure and socioeconomic conditions, highlighting the versatility of modeling approaches.

\subsection{Land Surface Temperature Projections in Cities}

Extreme heat is one of the most hazardous weather events, impacting human health, energy use, and ecosystems. Moreover, global climate models project that climate conditions associated with severe heat will become more intense, more frequent, and longer lasting (Meehl and Tebaldi 2004). By concentrating large populations and infrastructure in relatively small geographical areas, cities are particularly vulnerable to extreme heat. This vulnerability is exacerbated by warmer temperatures observed in cities, a phenomenon known as the urban heat island (UHI).

UHIs are a function of urban modification of the land surface, in turn altering its energy balance (Oke 1982). These modifications include reductions in natural 
cooling mechanisms like evapotranspiration and radiative cooling, along with the addition of heat sources like air conditioning and traffic. UHIs have also been shown to intensify during periods of extreme heat due to synergies between the surface and atmosphere (Li and Bou-Zeid 2013).

Traditionally, future climate is projected at continental to global scales using General Circulation Models (GCMs). GCMs are physical mathematical models that solve the equations of fluid motion and thermodynamics over the entire planet. However, computing resources limit the spatial resolution of GCMs to the order $10^{2} \mathrm{~km}(\mathrm{~km})$. Their coarse spatial resolution makes the use of GCMs problematic as a source of information on future climate hazards in cities, where physical features exist at less than $1 \mathrm{~km}$ scales. In addition, physical processes that occur at finer spatial scales than GCM grid resolution are often heavily parameterized (i.e., estimated using bulk or empirical relationships) or not present at all. Many of these processes are particularly important in urban settings, such as the effect buildings have on temperature and winds, as well as infrastructure (e.g., sewage and slopes) on flood extents. Two broad sets of techniques have been developed to address these shortcomings: dynamical and statistical downscaling.

Dynamical downscaling involves models that solve a similar set of equations as GCMs over a limited area, using GCM output data itself as initial and boundary conditions. In addition to employing higher resolution grids, dynamical downscaling can often represent smaller scale processes explicitly, such as convection, land surface dynamics, and clouds. However, availability of computing resources has traditionally limited this approach to simulations in the order of 1-10 km (i.e., neighborhood to city scales) for a limited number of regions (Kong et al. 2019).

On the other hand, statistical downscaling methods map observations to coarse GCM data to increase spatial resolution by use of additional data (e.g., land cover and weather station data). The main benefit of this approach lies in its low computational cost, with spatial resolution being limited by data availability of observations. With modern satellite imagery, observations often exist at the 0.01 to $0.1 \mathrm{~km}$ scale, where signals related to individual buildings can be explicitly resolved.

\subsubsection{Surface Temperature Projections at City Scales: New York City Case Study}

New York City (NYC), the most populous in the USA, faces challenges related to extreme summer heat. Studies have shown that the geographic distribution of temperatures is not uniform throughout the city (Ortiz et al. 2018). Assessment of heat risks is further complicated by the spatial variability of vulnerable groups in NYC (Rosenthal et al. 2014; Madrigano et al. 2015). This spatial variability necessitates the use of models of heat at fine spatial scales, accounting for the geography of the factors driving both temperature and vulnerability. 


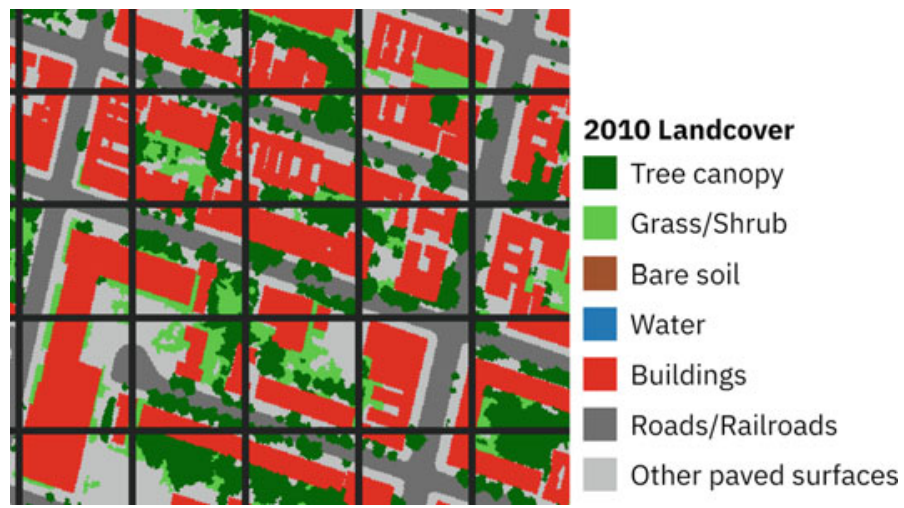

Fig. 9.1 60-m grid used to generate STURLA classes from land cover and building data in New York City

A statistical downscaling approach to derive urban surface temperature futures is to map satellite-derived surface temperatures to urban landscapes. Hamstead et al. (2016) show that by combining land cover with detailed building morphology data, urban landscapes could be classified into statistically separable composite classes with distinct surface temperature distributions. These Structure of Urban Landscape (STURLA) classes are derived by sampling land cover data within adjacent square grids, with each composite class made up of the contained land categories. (For more information about STURLA, see Chap. 4 on vulnerability mapping.) Fig. 9.1 shows a $60 \mathrm{~m}(\mathrm{~m})$ by $60 \mathrm{~m}$ grid over $1 \mathrm{~m}$ resolution land cover data in New York City using the 2010 LiDAR-derived land cover dataset. Present-day land surface temperature (LST) is estimated from Landsat 8 thermal imagery as described in Avdan and Jovanovska (2016).

The median LST for each class is then assigned to all cells of that class, so that there is a single LST value mapped to each. Once surface temperatures are mapped to present day imagery, a GCM ensemble is used to project future values. Rather than rely on a single global model as the source of future projections, a common approach is to use a group of simulations from different models. This approach addresses the uncertainty in the assumptions used in GCM formulations and their initial and boundary conditions. Here, an eight-member ensemble is used from the fifth Climate Model Intercomparison Project (CMIP5, Taylor et al. 2012) for an end of century (2070 to 2100) high emissions scenario (Representative concentration pathway 8.5, or RCP 8.5, Riahi et al. 2011). To project future LST, the composite land class-mapped LST is scaled using statistical standardization:

$$
L S T_{\text {standard }}=\frac{L S T_{i}-\overline{L S T}}{\sigma_{L S T}}
$$


where $L S T_{i}$ corresponds to the composite class-mapped temperature values and LST is the mean value, and $\sigma_{L S T}$ is the LST standard deviation. LST is then rescaled to using the GCM ensemble's 25th, 50th, and 75th quantiles to show the range of projections available:

$$
\Delta L S T=\Delta L S T_{G C M}+\left(\frac{\Delta L S T_{G C M}}{\sigma_{G C M}}\right) * L S T_{\text {standard }}
$$

Results (Fig. 9.2) provide insights into how the various composite urban landscapes may drive temperature change locally as global temperatures increase. For example, LST in relatively flat locations with little vegetation, such as airports, may warm more than in tree-lined areas with few to no buildings (e.g., Central Park). These fine-scale projections can be used to map future heat-related risk and vulnerability, as they provide information at spatial scales close to the size of housing units.

One limitation of this method is that physical processes at the land surface are not explicitly modeled, and thus nonlinear interactions between them may be underestimated or not accounted for at all. For example, droughts and dry soil conditions have been shown to greatly increase the intensity and frequency of heat waves (Fischer et al. 2007). Another limitation is that no temporal land use dynamics are considered. However, as LST change is mapped to specific classes, this method can be coupled with land cover models to explore their impacts on LST. With that approach, specific adaptations to increasing temperatures may be explored, offering stakeholders a measure of how adaptation measures may modify surface conditions and thus impact exposure to heat. These kinds of methods enable analysis of urban

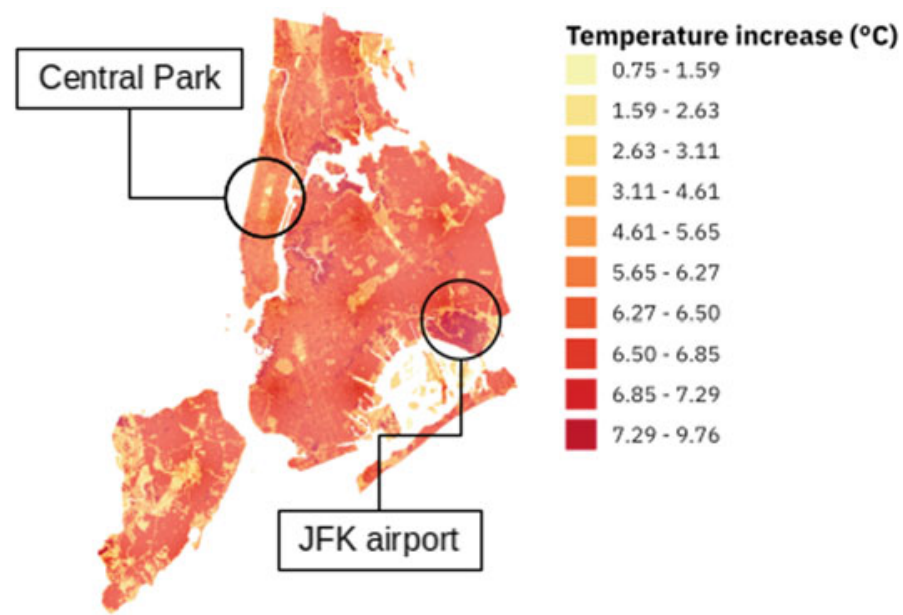

Fig. 9.2 End of century (2070-2100) landscape-mapped surface temperature projections based on the eight-member General Circulation Model RCP8.5 emissions scenario ensemble median values 
heat. By tying landscapes to surface temperatures, impacts of urban transformations may be explored, either in the form of heat adaptation or urban development.

\subsection{Urban Flooding}

Flooding poses an increasing threat worldwide, causing disruption, economic damages and loss of life (Jha et al. 2012). Contemporary cities face risk from multiple types and combinations of meteorologically driven flooding (Moftakhari et al. 2017). These include types that have been well studied, such as fluvial and coastal flooding, along with flooding types that have only recently begun to receive attention, such as pluvial and groundwater flooding (Box 9.1).

\section{Box 9.1 Types of flooding events and their definitions}

Flooding types

Fluvial/Lakeshore Flooding: Flooding that occurs when the stage of rivers, streams or other freshwater bodies rises above bankfull elevations and/or the height of levees or flood protection infrastructure.

Coastal Flooding: Flooding that occurs when tide levels exceed an elevation threshold that results in the inundation of infrastructure or disruption of socioeconomic activities.

Pluvial Flooding: Flooding that occurs when precipitation rates exceed the rate of natural or engineered drainage, resulting in overland inundation and/or flow.

Groundwater Flooding: Flooding that occurs when groundwater tables rise above a threshold level that results in the inundation of infrastructure or disruption of socioeconomic activities.

Due to global climate change, the frequency and intensity of all of these flooding mechanisms are projected to increase in many regions of the world (Rotzoll and Fletcher 2013; Arnell and Gosling 2016; Vitousek et al. 2017; Rosenzweig et al. 2018). However, climatic drivers will interplay dynamically with land use pathways to dynamically determine flood risk. LUC models can be used to enhance understanding of how land use changes can impact all three components of flood risk, outlined below (Crichton 1999; Koks et al. 2015).

- Exposure: The population, property and assets located in inundated areas.

- Social vulnerability: The sensitivity of social, ecological and infrastructure systems to the impacts of inundation when and where it occurs

- Hazard: The probability that inundation will occur.

Many studies have used LUC models to assess flooding exposure. This is typically done using a decoupled approach, where future land use and inundated area are 
simulated independently and the results then compared (Barredo and Engelen 2010; Cammerer et al. 2013; Beckers et al. 2013; Song et al. 2017). While these decoupled approaches can provide valuable information to support urban planning, it is important to consider that cities are integrated social-ecological-technological systems and that "social" land-use planning decisions will determine not just who is living in potentially inundated areas but will also affect the area inundated in response to a meteorological or climatological hazard. For example, the dense encroachment of buildings onto the floodplain can affect exposure during a flooding event (Fig. 9.3).

LUC models can also be used to enhance understanding of social vulnerability to flooding under different scenarios. For any given population or settlement exposed to flooding, the severity of impact is associated with social parameters such as wealth, type of infrastructure, and/or the availability of insurance or other social instruments that support recovery from inundation. For example, informal settlements are known to be highly vulnerable to flooding in the absence of specialized mitigation efforts (Jiusto and Kenney 2016). LUC models can be used to assess the effectiveness of policies to disincentivize the expansion of informal settlements in the floodplain, thus reducing future social vulnerability to flooding (Inouye et al. 2015).

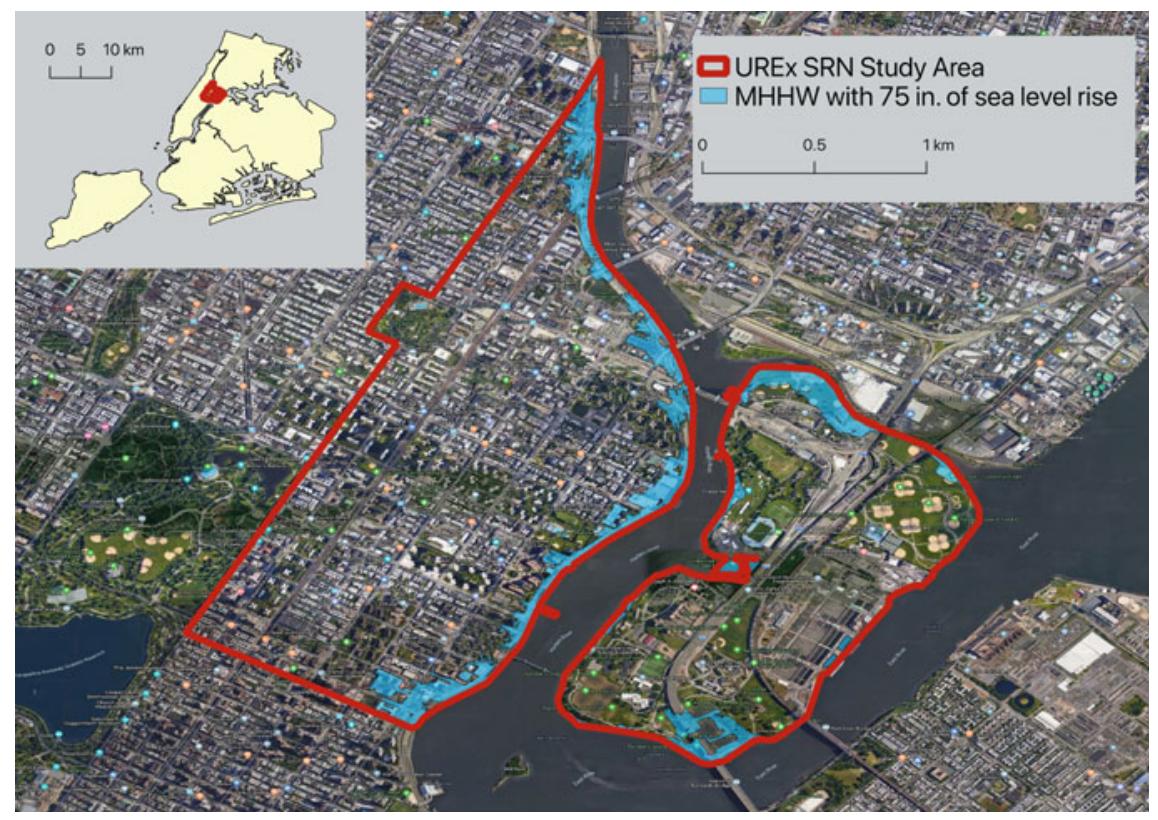

Fig. 9.3 New York City's East Harlem/Randalls Island community with the event of $1.9 \mathrm{~m}$ (75 inches) of sea-level rise. In this scenario, $11 \%$ of this community would be inundated during a typical daily high tide (Mean Highest High Water, or MHHW). Through the Urban Resilience to Extremes Sustainability Research Network (URExSRN), researchers are using cellular automata to investigate exposure under alternative land use scenarios 
Finally, several studies have identified the potential impact of urban land use development on local meteorological hazards, those of which may result in urban flooding. Conventionally, meteorological hazards were seen as external, independent drivers of flooding. However, recent studies have found that urban canopy and heat island (Lin et al. 2011; Han et al. 2014) effects can impact the evolution and rainfall of both thunderstorms and longer duration extreme rain events, such as Hurricane Harvey in 2018 (Zhang et al. 2018). LUC models can be used to better understand these feedbacks and the integrated dynamics of land use and climate change that can determine future flood risk.

\subsection{Modeling Future Land Use/Cover Change Scenarios}

Recently, envisioning positive futures has gained traction as a method of designing desirable outcomes in cities (see Chap. 6; McPhearson et al. 2016). This visioning process gives stakeholders, policymakers, and communities an opportunity to set goals and transitions that not only make urban growth more sustainable and resilient to climate hazards but also improve the services they provide. One way to make the visioning processes spatially explicit is through spatially explicit mathematical land use models.

LUC models seek to understand the drivers of LUC dynamics (Mustafa et al. 2018b) and/or simulate possible future scenarios (Hyandye and Martz 2017). Several modeling approaches have been proposed to analyze land change patterns. Broadly, these approaches are cellular automata $(\mathrm{CA})$, agent-based $(\mathrm{AB})$, and statistical models. Among these, CA has been widely used due to its simplicity, explanatory power, and ability to represent LUC evolution (Troisi 2015). The CA framework (Basse et al. 2014; Hyandye and Martz 2017; Mustafa et al. 2018a) is a spatially explicit model in which the change from one land use to another (e.g., from forest to urban) is controlled by the states of neighboring locations (called cells in this context). Although pure CA models cannot account for important global LUC change drivers (e.g., distance to roads and slope angles), newer approaches have coupled them to statistical models (e.g., logistic regression) in order to include their influence. AB models (Zhuge et al. 2016; Mustafa et al. 2017) allow the exploration of interactions between different spatial scales (e.g., urban developers and the environment, Mialhe et al. 2012). These models incorporate individuals' behavior and their interactions in the land change process.

Subsequent subsections detail a case study of the use of CA models as a tool to coproduce spatially explicit visions of the future for the Caribbean city of San Juan, Puerto Rico. In this study, we employ the Dinamica Environment for Geoprocessing Objects (EGO), a CA-based model, to simulate possible future land use scenarios of San Juan, Puerto Rico. Unlike typical CA models that use descriptive logistic regression or other static methods to calibrate the relationship between land use change process and its drivers, Dinamica uses the weight of evidence (WoE) method, which has been shown to offer more flexibility in modeling these relationships (Kolb 
et al. 2013; Pathirana et al. 2014; Gago-Silva et al. 2017). WoE methods use the concept of conditional probability to estimate the weight given to all driving variables as they occur (or not) in historical datasets. This has the effect of modifying the direct impact of each dataset on LUC change, with this weighting being updated with new data. As reproducing these relationships is crucial to simulate LUC change dynamics, Dinamica has been widely employed in this domain.

\subsubsection{Land Use/Cover Scenarios Modeling: San Juan, Puerto Rico Case Study}

Following the coproduction framework detailed in Chap. 6, we developed three distinct, long-term future (2080) visions of the coastal city of San Juan, Puerto Rico: Food \& Energy Security, Coastal and Flooding, and Connected Cities. Each scenario's objectives and priorities were used to modify the conversion rates of respective land cover types using a CA model trained on historical data, as detailed in Table 9.1. These objectives and goals were developed via a series of activities, which included participatory mapping and development of timelines and milestones for each scenario.

In the San Juan case study, the CA model is trained on two LUC datasets: 1991 and 2000. The LUC data, at $10 \mathrm{~m}$ spatial resolution, have been reclassified

Table 9.1 Coproduced future scenarios for San Juan, Puerto Rico with their objectives and corresponding cellular automata model rule modifications

\begin{tabular}{l|l|l}
\hline Scenario name & Objectives & Modeling transition rules \\
\hline Food and energy security & $\begin{array}{l}\text { Ecotone restoration (wetland } \\
\text { and riverine) } \\
\text { Use of vacant land for urban and } \\
\text { periurban agriculture }\end{array}$ & $\begin{array}{l}\text { Increase conversion to wetlands } \\
\text { near coast by 10\% } \\
\text { Increase conversion to forest near } \\
\text { water land use cells } \\
\text { Generate small agriculture } \\
\text { patches within urban areas }\end{array}$ \\
\hline Flooding & $\begin{array}{l}\text { Reforestation } \\
\text { Relocation of coastal } \\
\text { communities to inland locations } \\
\text { to strengthen coastal ecosystems } \\
\text { and reduce flood risk, starting } \\
\text { from 2050 }\end{array}$ & $\begin{array}{l}\text { Increase conversion to forest } \\
\text { throughout entire domain } \\
\text { urban areas near coast } \\
\text { Increase conversion rates from } \\
\text { bare soil to forests }\end{array}$ \\
\hline Connected cities & $\begin{array}{l}\text { Increase connectivity of } \\
\text { transportation infrastructure } \\
\text { Rivers and lakes as part of } \\
\text { transportation system } \\
\text { Reforestation near coast and } \\
\text { other water bodies to restore } \\
\text { watershed } \\
\text { Reduced development near coast }\end{array}$ & $\begin{array}{l}\text { Increase conversion to forest } \\
\text { throughout entire domain } \\
\text { From 2050 onward, decrease } \\
\text { development of urban areas near } \\
\text { coast } \\
\text { Increase conversion to forest near } \\
\text { inland water bodies }\end{array}$ \\
\hline
\end{tabular}


into 10 categories: Sea, High-density urban, Low-density urban, Cultivated lands, Pasture, Forests, Wetlands, Coastal sand, Bare soil, and Inland water. In addition, several global drivers of LUC change are included in the model: distances to barrios, road network, airport, vial, lakes, ports, and rivers, as well as protected zones and floodplains.

The change rate from one LUC to another per time step, representing 1 year, is obtained in the CA model by a cross-tabulation between the two LUC maps. Transition rules used to allocate LUC change consists of two components. The first is calculated using the LUC change global drivers. The second component is based on the local neighbors of each cell. Dinamica calculates the transition probability based on global drivers using the WoE method.

After calculating the transition probabilities based on the explanatory variables, Dinamica uses CA model to calculate transition probabilities according to the immediate neighbors for each cell. This is done using two complementary functions: Expander and Patcher. Along with mimicking local neighborhood influence, these functions allow for controlling the geometry of the simulated patches by estimating the mean size, size variance, and isometry of the patches.

\subsubsection{San Juan Simulation Results}

Simulation results reveal significant differences between the scenarios (Fig. 9.4), consistent with their corresponding stakeholder-stated objectives. In addition to the three coproduced future scenarios, a "business-as-usual" (BAU) scenario was also generated. Development of BAU followed the same modeling approach detailed above, but without any modification of land transition rules, representing a projection of future San Juan based entirely on historical LUC change.

In the Food and Energy Security scenario, green corridors appear along rivers (forest and cultivated patches), with wetland increasing near riverbeds and coastal areas by 2080. In addition, urban development is characterized by a low rather than high density urban fabric, which is predominant in the BAU scenario.

The flooding scenario shows massive reforestation and a relocation of coastal communities. This relocation is coupled with development of catchments to reduce flooding vulnerability, one of the stated scenario goals. This reduced flooding exposure is evident when overlaying the modeled LUC scenarios with the FEMA 500-year floodplain. Total urban area exposed to flooding by the year 2080 is lowest in the Flooding scenario.

The 2080 Connected City simulation is mainly characterized by a pattern of urbanization (including high-density urban) integrated with an increase in green space. The outcome is largely urbanized, but with many corridors and patches of green cover, wetlands and riverine forest (Fig. 9.5). 

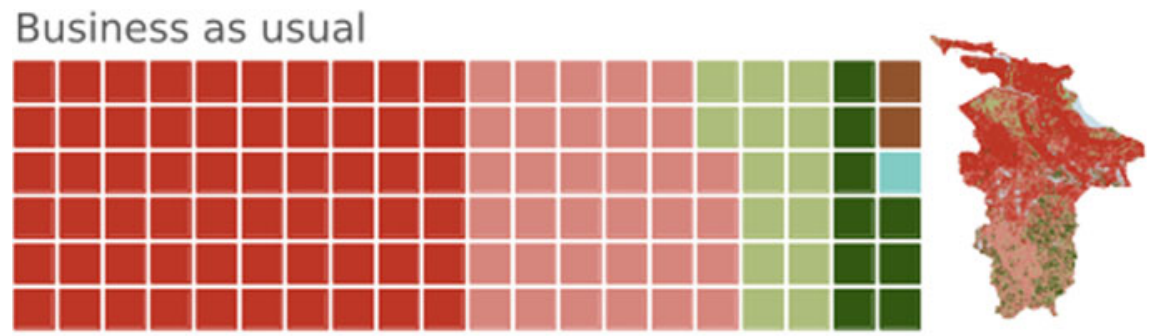

\section{Flooding}
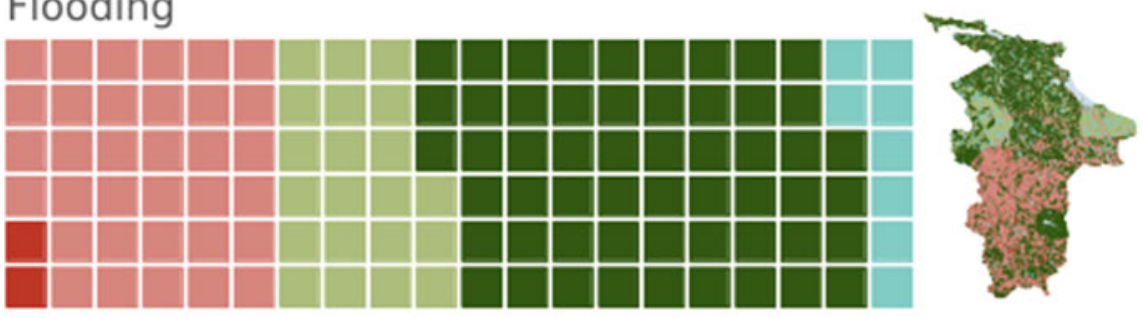

Connected Cities
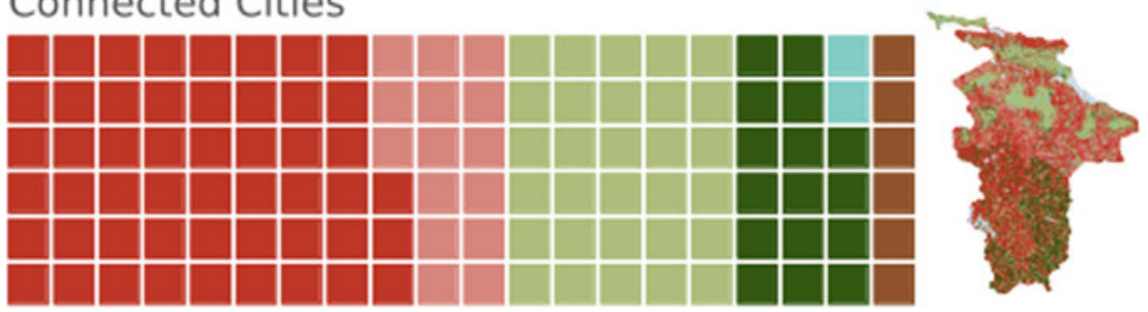

Food \& Energy Security
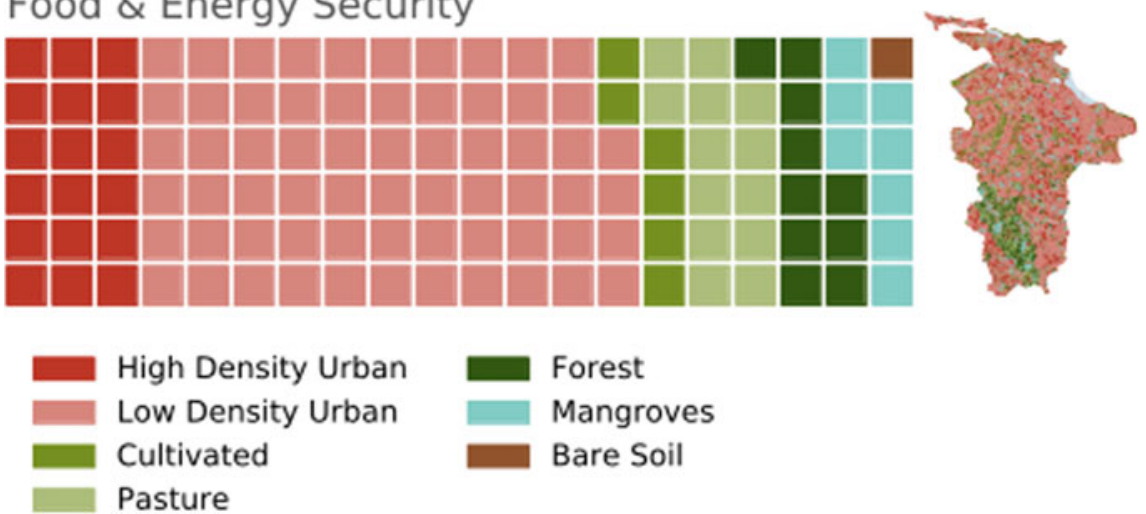

Bare Soil

Fig. 9.4 Modeled land use/cover change scenarios. The gridded waffle diagram shows the relative composition by land use/cover category 

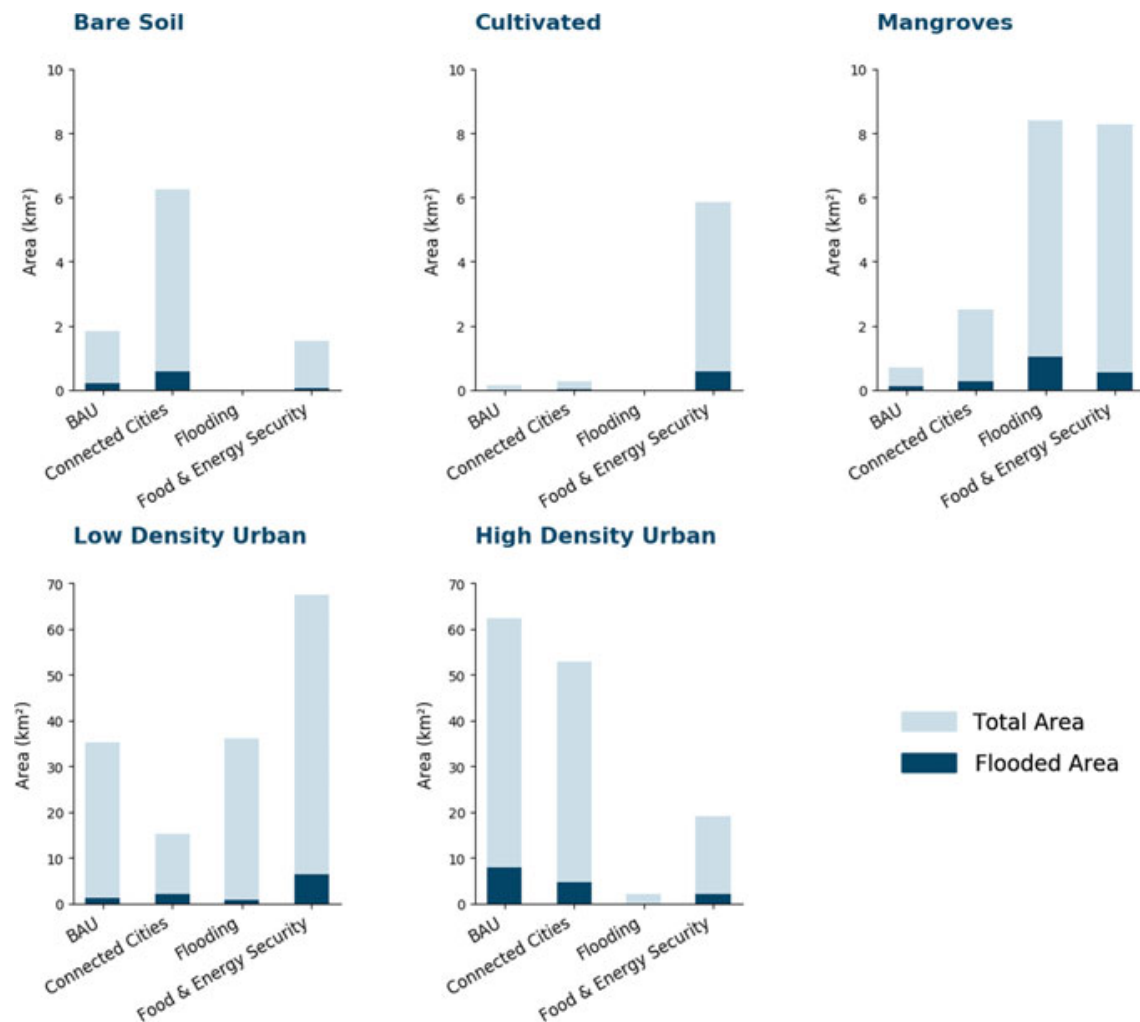

Total Area

Flooded Area

Fig. 9.5 Total and flooded area for selected land use/cover categories in the business as usual and three coproduced land use/cover scenarios

\subsection{Conclusion}

Weather hazards-projected to become more frequent and intense-pose a large threat to cities and the people in them. The complexity and scale of these threats will require adaptation strategies of commensurate scale. As cities grapple with these challenges, land development will need to account for not just how land use affects services, but how it may also drive future hazards. In this chapter, we showed datadriven approaches to estimate the impacts of LUC on heat and flood risks. These approaches, coupled with the use of CA models, can provide urban planners and policymakers with the tools to not just develop LUC plans, but to also fully explore their impacts on heat and flood risks.

Coupled with participatory production of future visions, these models can provide tools needed to explicitly identify goal tradeoffs. For example, relocating coastal communities may protect them from flood risk, but may also expose them to 
higher temperatures. Explicitly modeling LUC change can also form an iterative coproduction process, where potential scenarios and associated impacts are modified to minimize negative impacts while optimizing positive outcomes.

As data collection efforts increase, so will the utility of these models. Future models may include risks to urban infrastructure such as exposure of electric substations to flood plains in present and future scenarios, or extreme heat in underground subway stations. More elaborate models might include risks of combined hazards (e.g., heat waves followed by power failure due to a flood event), and allow stakeholders to build resilience to them into planning efforts.

With global climate change increasing the severity and frequency of many types of weather hazards, tools to study risks related to the spatial features of cities will be of increasing necessity. Spatially explicit mapping of these hazards will allow policy to address impacts across populations and account for vulnerability in new ways.

\section{References}

Arnell NW, Gosling SN (2016) The impacts of climate change on river flood risk at the global scale. Clim Change 134(3):387-401. https://doi.org/10.1007/s10584-014-1084-5

Avdan U, Jovanovska G (2016) Algorithm for automated mapping of land surface temperature using LANDSAT 8 satellite data. J Sensors 2016:1-8. https://doi.org/10.1155/2016/1480307

BarredoJIEG (2010) Land use scenario modeling for flood risk mitigation. Sustainability 2(5):13271344. https://doi.org/10.3390/su2051327

Basse RM, Omrani H, Charif O et al (2014) Land use changes modelling using advanced methods: cellular automata and artificial neural networks. The spatial and explicit representation of land cover dynamics at the cross-border region scale. ApplGeogr 53:160-171. https://doi.org/10.1016/ j.apgeog.2014.06.016

Beckers A, Dewals B, Erpicum S et al (2013) Contribution of land use changes to future flood damage along the river Meuse in the Walloon region. Nat Hazards Earth Syst Sci 13:2301-2318. https://doi.org/10.5194/nhess-13-2301-2013

Caldwell P, Chin H-NS, Bader DC et al (2009) Evaluation of a WRF dynamical downscaling simulation over California. Clim Change 95(3-4):499-521. https://doi.org/10.1007/s10584-0099583-5

Cammerer H, Thieken AH, Verburg PH (2013) Spatio-temporal dynamics in the flood exposure due to land use changes in the Alpine Lech Valley in Tyrol (Austria). Nat Hazards 68(3):1243-1270. https://doi.org/10.1007/s11069-012-0280-8

Coumou D, Robinson A (2013) Historic and future increase in the global land area affected by monthly heat extremes. Environ Rese Lett 8(3):034018. https://doi.org/10.1088/1748-9326/8/3/ 034018

Crichton D (1999) The Risk Triangle. Nat Disaster Manage 102:103

Fischer EM, Seneviratne SI, Vidale PL et al (2007) Soil moisture-atmosphere interactions during the 2003 European summer heat wave. J Clim 20(20):5081-5099. https://doi.org/10.1175/JCL I4288.1

Gago-Silva A, Ray N, Lehmann A (2017) Spatial dynamic modelling of future scenarios of land use change in Vaud and Valais. Western Switzerland. ISPRS Int J Geo-Inf 6(4):115. https://doi. org/10.3390/ijgi6040115

HamsteadZA KP, Larondelle N et al (2016) Classification of the heterogeneous structure of urban landscapes (STURLA) as an indicator of landscape function applied to surface temperature in New York City. Ecol Indic 70:574-585. https://doi.org/10.3390/su10030645 
Han J-Y, Baik J-J, Lee H (2014) Urban impacts on precipitation. Asia-Pacific J Atmos Sci 50(1):1730. https://doi.org/10.1007/s13143-014-0016-7

Hyandye C, Martz LW (2017) A Markovian and cellular automata land-use change predictive model of the Usangu Catchment. Int J Remote Sens 38(1):64-81. https://doi.org/10.1080/014 31161.2016.1259675

Inouye CEN, de Sousa WC, de FreitasDM, et al (2015) Modelling the spatial dynamics of urban growth and land use changes in the north coast of São Paulo, Brazil. Ocean Coastal Manage 108:147-157. https://doi.org/10.1016/j.ocecoaman.2014.12.016

Jha AK, Bloch R, Lamond J (2012) Cities and flooding: a guide to integrated urban flood risk management for the 21st Century. the World Bank. https://doi.org/10.1596/978-0-8213-8866-2

Jiusto S, Kenney M (2016) Hard rain gonna fall: strategies for sustainable urban drainage in informal settlements. Urban Water J 13(3):253-269. https://doi.org/10.1080/1573062X.2014.991329

Koks EE, Jongman B, Husby TG et al (2015) Combining hazard, exposure and social vulnerability to provide lessons for flood risk management. Environ Sci Policy 47:42-52. https://doi.org/10. 1016/j.envsci.2014.10.013

Kolb M, Mas J-F, Galicia L (2013) Evaluating drivers of land-use change and transition potential models in a complex landscape in Southern Mexico. Int J GeogInf Sci 27(9):1804-1827. https:// doi.org/10.1080/13658816.2013.770517

Kong X, Wang A, Bi X et al (2019) Assessment of temperature extremes in China using RegCM4 and WRF. Adv Atmos Sci 36(4):363-377. https://doi.org/10.1007/s00376-018-8144-0

Krayenhoff ES, Moustaoui M, Broadbent AM et al (2018) Diurnal interaction between urban expansion, climate change and adaptation in US cities. Nat Clim Change 8(12):1097. https://doi. org/10.1038/s41558-018-0320-9

Li D, Bou-Zeid E (2013) Synergistic interactions between urban heat islands and heat waves: the impact in cities is larger than the sum of its parts. J ApplMeteorolClimatol 52(9):2051-2064. https://doi.org/10.1175/JAMC-D-13-02.1

Lin CY, Chen WC, Chang PL et al (2011) Impact of the urban heat island effect on precipitation over a complex geographic environment in Northern Taiwan. J ApplMeteorolClimatol 50(2):339-353. https://doi.org/10.1175/2010JAMC2504.1

Madrigano J, Ito K, Johnson S et al (2015) A case-only study of vulnerability to heat wave-related mortality in New York City (2000-2011). Environ Health Perspect 123(7):672-678. https://doi. org/10.1289/ehp.1408178

McPhearson T, IwaniecDM BX (2016) Positive visions for guiding urban transformations toward sustainable futures. CurrOpin Environ Sustain 22:33-40. https://doi.org/10.1016/j.cosust.2017. 04.004

Meehl GA, Tebaldi C (2004) More intense, more frequent, and longer lasting heat waves in the 21st century. Sci 305(5686):994-997. https://doi.org/10.1126/science.1098704

Mialhe F, Becu N, Gunnell Y (2012) An agent-based model for analyzing land use dynamics in response to farmer behaviour and environmental change in the Pampanga delta (Philippines). AgricEcosyst Environ 161:55-69. https://doi.org/10.1016/j.agee.2012.07.016

Moftakhari HR, AghaKouchak A, Sanders BF et al (2017) Cumulative hazard: the case of nuisance flooding. Earth's Future 5(2):214-223. https://doi.org/10.1002/2016EF000494

Mustafa A, Cools M, Saadi I et al (2017) Coupling agent-based, cellular automata and logistic regression into a hybrid urban expansion model (HUEM). Land Use Policy 69:529-540. https:// doi.org/10.1016/j.landusepol.2017.10.009

Mustafa A, Heppenstall A, Omrani H et al (2018) Modelling built-up expansion and densification with multinomial logistic regression, cellular automata and genetic algorithm. Comput Environ Urban Syst 67:147-156. https://doi.org/10.1016/j.compenvurbsys.2017.09.009

Mustafa A, Van Rompaey A, Cools Met al (2018) Addressing the determinants of built-up expansion and densification processes at the regional scale. Urban Stud 55(15):3279-3298. https://doi.org/ $10.1177 / 0042098017749176$

OkeTR, (1982) The energetic basis of the urban heat island . Q J R MeteorologSoc 108(455):1-24. https://doi.org/10.1002/qj.49710845502 
Ortiz LE, González JE, Horton R et al (2019) High-resolution projections of extreme heat in New York City. Int J Climatol 39(12):4721-4735. https://doi.org/10.1002/joc.6102

Ortiz LE, Gonzalez JE, Wu W et al (2018) New York city impacts on a regional heat wave. J ApplMeteorolClimatol 57(4):837-851. https://doi.org/10.1175/JAMC-D-17-0125.1

Pathirana A, DenekewHB VW et al (2014) Impact of urban growth-driven landuse change on microclimate and extreme precipitation-a sensitivity study. Atmos Res 138:59-72. https://doi. org/10.1016/j.atmosres.2013.10.005

Riahi K, Rao S, Krey V et al (2011) RCP 8.5-a scenario of comparatively high greenhouse gas emissions. Clim Change 109:33. https://doi.org/https://doi.org/10.1007/s10584-011-0149-y

Rosenthal J, Kinney PL, Metzger KB (2014) Intra-urban vulnerability to heat-related mortality in New York City, 1997-2006. Health Place 30:45-60. https://doi.org/10.1016/j.healthplace.2014. 07.014

Rosenzweig BR, McPhillips L, Chang H et al (2018) Pluvial flood risk and opportunities for resilience . Wiley Interdiscip Rev: Water 5(6):e1302. https://doi.org/10.1002/wat2.1302

Rotzoll K, Fletcher CH (2013) Assessment of groundwater inundation as a consequence of sea-level rise. Nat Clim Change 3(5):477-481. https://doi.org/10.1038/nclimate1725

Song K, Kwon N, Anderson K et al (2017) Predicting hourly energy consumption in buildings using occupancy-related characteristics of end-user groups. Energy Build 156:121-133. https:// doi.org/10.1016/j.enbuild.2017.09.060

Taylor KE, Stouffer RJ, Meehl GA (2012) An overview of CMIP5 and the experiment design. Bull Am MeteorolSoc 93(4):485-498. https://doi.org/10.1175/BAMS-D-11-00094.1

Troisi A (2015) Can CA describe collective effects of polluting agents? Int J Mod Phys C 26(10):1550114. https://doi.org/10.1142/S0129183115501144

Vitousek S, Barnard PL, Fletcher CH et al (2017) Doubling of coastal flooding frequency within decades due to sea-level rise. Sci Rep 7(1):1399. https://doi.org/10.1038/s41598-017-01362-7

Zhang W, Villarini G, Vecchi GA et al (2018) Urbanization exacerbated the rainfall and flooding caused by hurricane Harvey in Houston. Nat 563(7731):384. https://doi.org/10.1038/s41586-0180676-z

Zhuge C, Shao C, Gao J et al (2016) Agent-based joint model of residential location choice and real estate price for land use and transport model. Comput Environ Urban Syst 57:93-105. https:// doi.org/10.1016/j.compenvurbsys.2016.02.001

Luis Ortiz is a postdoctoral research fellow with the Urban Systems Lab at The New School. A mechanical engineer by training, he is interested in the intersection of built environments, humans, and the atmosphere. In particular, he is interested in how climate change impacts energy use and health, as well as how cities may mitigate and adapt to these impacts. He uses both physical and statistical techniques to model feedbacks between buildings and the air around them and how they might change under a warming climate. His work on extreme heat projections was featured in the New York City Panel on Climate Change third report, where he co-authored the chapter on advances in climate science.

\begin{abstract}
Ahmed Mustafa is a spatial data scientist with expertise in urban studies. His research focuses on using methodological approaches that work with complex data sources to study urban systems. He is currently working on developing and implementing computational models to simulate spatial patterns of future cities within the NSF UREx SRN and the NSF Convergence SETS for Urban Resilience projects.
\end{abstract}

Bernice R. Rosenzweig is an Assistant Professor of Environmental Science at Sarah Lawrence College in Bronxville, New York. Her research investigates the resilience of urban socio-technical systems to extreme meteorological events. Her current work focuses on post-industrial cities in the northeast United States. 
Rocio Carrero is a Faculty Fellow at the Urban Systems Lab and an environmental geoscientist interested in testing experimental models to explore urban resilience. As part of Urban Resilience to Extremes (UREx) network's Scenario Modeling Task Force, she worked on developing computational Cellular Automata models to spatially simulate future scenarios.

Timon McPhearson is Director of the Urban Systems Lab and Associate Professor of Urban Ecology at The New School. He is a Research Fellow at The Cary Institute of Ecosystem Studies and Stockholm Resilience Centre and a member of the IPCC.

Open Access This chapter is licensed under the terms of the Creative Commons Attribution 4.0 International License (http://creativecommons.org/licenses/by/4.0/), which permits use, sharing, adaptation, distribution and reproduction in any medium or format, as long as you give appropriate credit to the original author(s) and the source, provide a link to the Creative Commons license and indicate if changes were made.

The images or other third party material in this chapter are included in the chapter's Creative Commons license, unless indicated otherwise in a credit line to the material. If material is not included in the chapter's Creative Commons license and your intended use is not permitted by statutory regulation or exceeds the permitted use, you will need to obtain permission directly from the copyright holder. 